\title{
Ecological studies of the cyclorrhaphous flies under urban and suburban environments in Tokyo and a neighbouring city
}

\author{
Hideyuki Missuı \\ Tokyo Metropolitan Yamasaki Highschool, Machida, Tokyo, 195 Japan
}

(Received: 15 November 1995; Accepted: 6 February 1996)

\begin{abstract}
Key words: Diptera, Cyclorrhapha, ecological distribution, putrid flesh trap, urban and suburban environments
\end{abstract}

\begin{abstract}
Community structure and ecological distribution of flies (Diptera, Cyclorrhapha) attracted to putrid flesh traps in the urban and suburban areas in Tokyo were studied from January 1990 to November 1992. Trapping sites were classified into eight types, and 179 species of flies belonging to twenty four families were collected. The trapping site similarities were clustered by Pianka's $\alpha$ index. Composition rate of 47 dominant species in each trapping site was analyzed.
\end{abstract}

\section{INTRODUCTION}

The fly fauna of the urban area in Tokyo has been changing with its urbanization (Kurahashi, 1982). Recently, some important insect pests, such as Musca domestica or Fannia canicularis have almost disappeared in the urban area. However, many other flies, which emerge from small breeding media, are still common (Mitsui, 1994). In order to characterize the present urban fly community, periodical surveys were carried out by using traps baited with putrid flesh in an urban area (Ohta-ku, Tokyo) and a suburban area (Tokorozawa City, Saitama Prefecture).

\section{Methods and Surveyed Areas}

Periodical surveys were carried out once a month from January 1990 to November 1992 (except for Jan. and Feb. 1992) using the handmade fruit traps (Mitsui, 1992) baited with minced pork. A trap in each trapping site was set for two weeks in each investigation and then col- lected. The flies trapped were preserved in $70 \%$ ethanol and identified later.

Eight trapping sites were as follows:

A: In front of Kamata station, which is surrounded by business quarters.

B: Backyard of government building of Ohta-ku, which is surrounded by residential area with few garden trees or flower beds.

C: Highschool ground, which is surrounded by residential area with plenty of garden trees or flower beds.

D: Deciduous broad-leaved forest of Tamagawadai park.

E: Deciduous broad-leaved forest of Waseda University Tokorozawa campus, which is situated in the edge of Sayama hill and adjacent to the relatively developed housing area.

F: Deciduous broad-leaved forest which extends somewhat far back from the forest $\mathrm{E}$.

G: Lowland marsh, which neighbours on forest $F$ and had been utilized as paddy field previously.

H: Lawn ground in Waseda University campus.

A to D-Urban area (Ohta-ku, Tokyo), E 
to $\mathrm{H}$-Suburban area (Tokorozawa City, Saitama Prefecture).

\section{RESUlts}

One hundred and seventy nine species belonging to 24 families, totaling 18,754 individuals of cyclorrhaphous flies were collected throughout the survey period.

Similarities of the species compositions and its frequencies in each trapping site were calculated using Pianka's $\alpha$ index (Pianka, 1973), and the results were subjected to a cluster analysis using averagelinkage method. As a result of the analysis, eight trapping sites were classified into the following four clusters (Fig. 1).
A: business quarters
$B$ and $C$ : residential area
$\mathrm{D}, \mathrm{E}$ and $\mathrm{F}$ : forest
$\mathrm{G}$ and $\mathrm{H}$ : grassy area

Subsequently the environmental preference of the flies was examined. For examinating the results, the flies constituting $85 \%$ of the total number in each trapping site were selected as dominant spe-

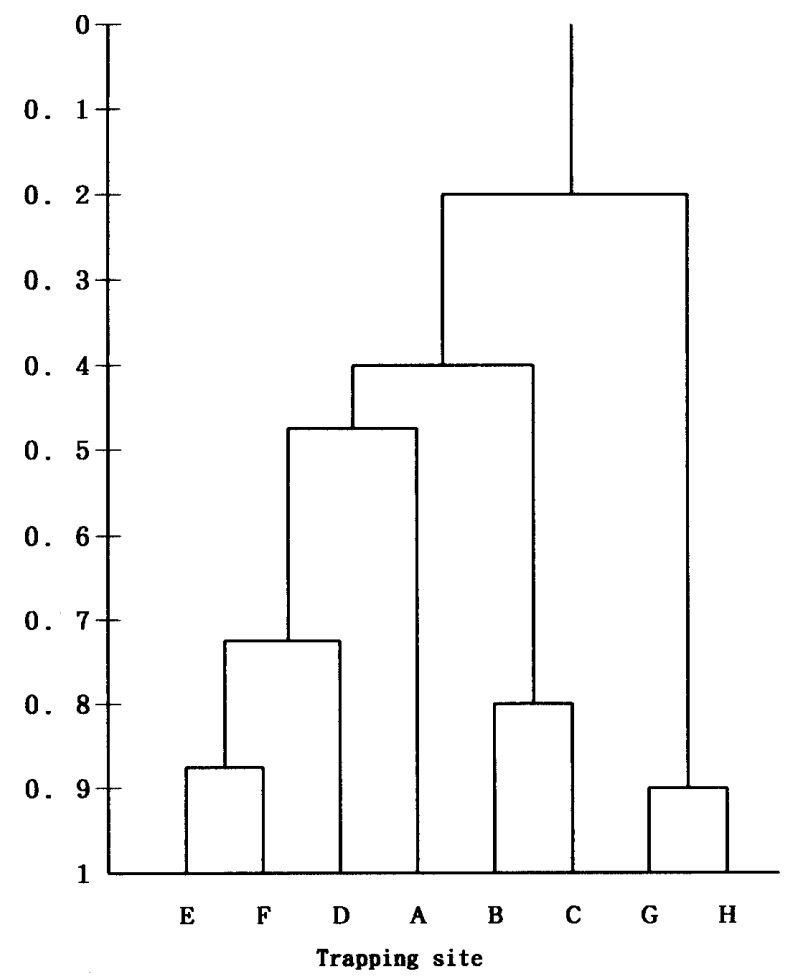

Fig. 1. Dendrogram of trapping site similarities clustered by Pianka's $\alpha$ index. cies. The dominant species selected in such a way were 47 species belonging to 15 families. As the result of examination, they were classified into five groups which corresponded to the four clusters of environment (Table 1). The five groups were as follows:

Group I: Flies were collected mainly in the forests.

Group II: Flies were collected commonly in the forests and grassy areas.

Group III: Flies were collected chiefly in the grassy areas.

Group IV: Flies were collected commonly in the residential areas.

Group V: Flies were collected mainly in the business quarters.

Furthermore, each group was classified into the following three subgroups judging from the fly species collected in the urban area (Table 1).

Subgroup a: Few flies were collected in the whole urban area.

Subgroup b: Few flies were collected in the business quarters and the residential areas (especially in the area with few garden trees or flower beds).

Subgroup c: Flies were collected commonly in the residential areas and the business quarters.

Among the 47 dominant species, 25 species belong to the group I. The species belonging to the subgroup I-a were not domiciled ones in the small urban forest. The following nine species, Puliciphora sp. 1 (Phoridae), Dryomyza formosa (Dryomyzidae), Drosophila coracina, D. curviceps (Drosophilidae), Fannia edentula (Fanniidae), Muscina angustifrons (Muscidae), Calliphora nigribarbis, Lucilia porphirina, and Chrysomya pinguis (Calliphoridae) belong to the subgroup I-b, and they were the main members of the fly communities both in the urban and suburban forests. Eight species, Diplonevra peregrina, Megaselia spiracularis, $M$. sp. 1, Puliciphora sp. 2 

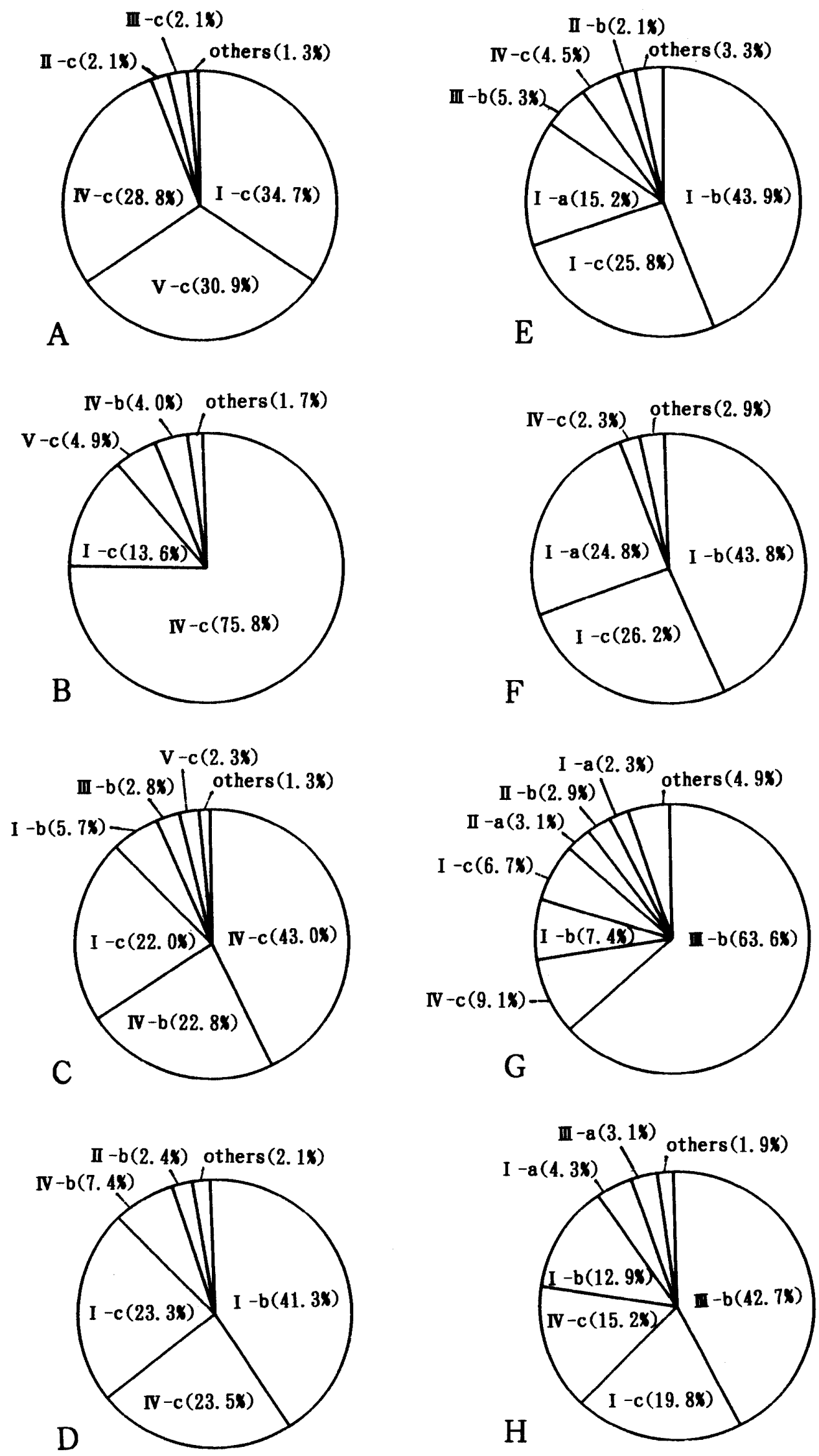

Fig. 2. Percentage ratio of 12 subgroups constituted by the 47 dominant species in 8 trapping sites. 


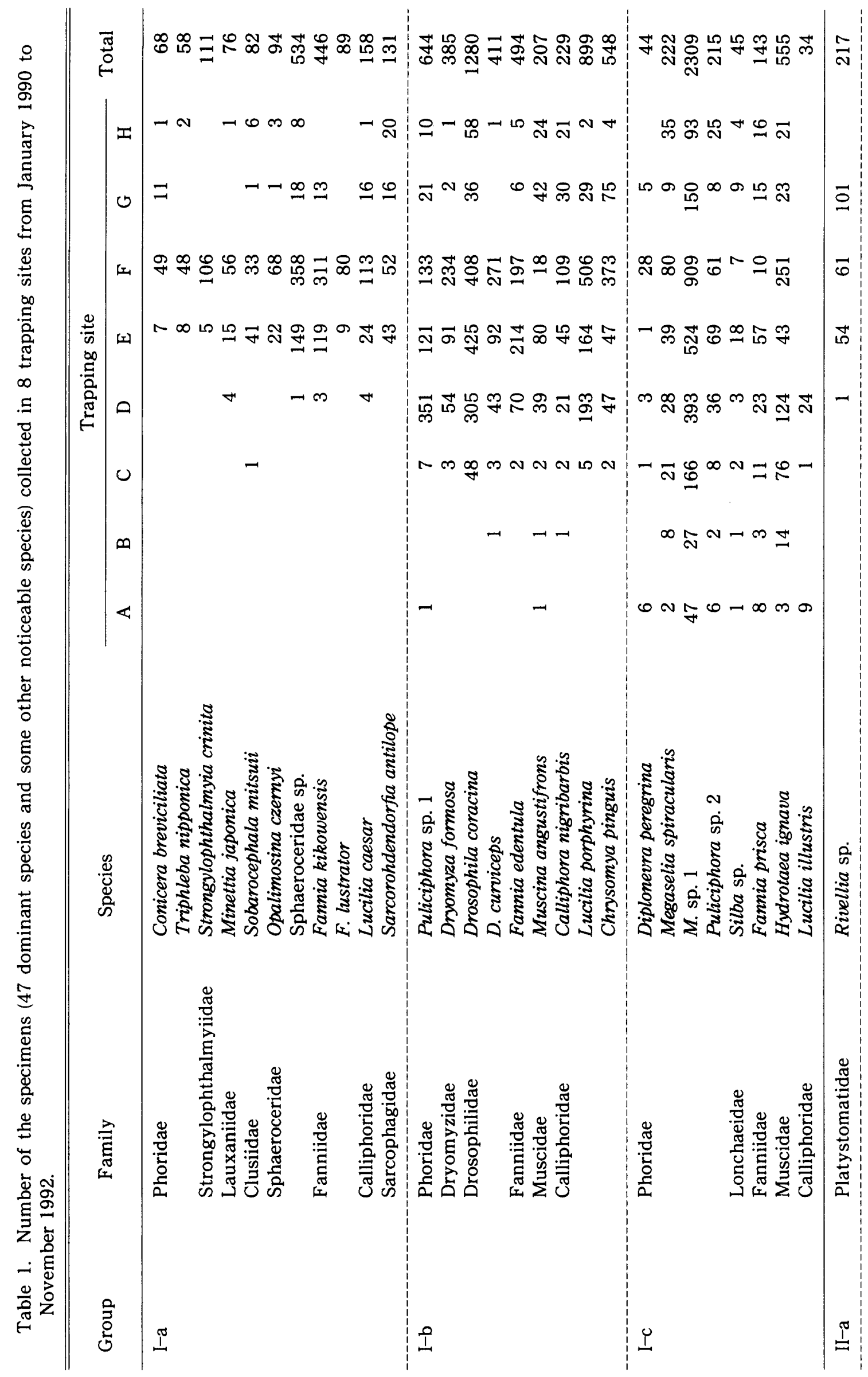




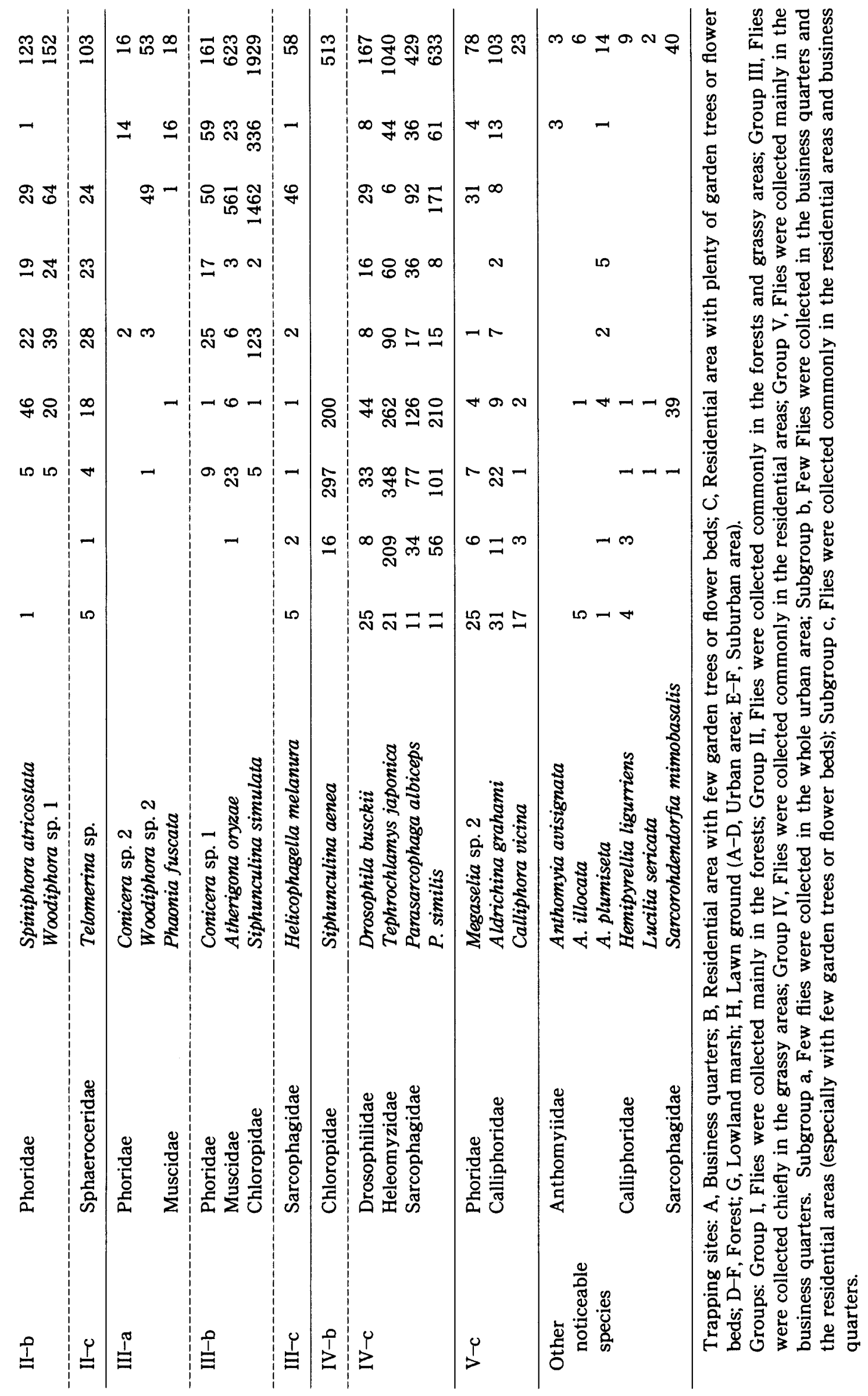


(Phoridae), Silba sp. (Lonchaeidae), Fannia prisca (Fanniidae), Hydrotaea ignava (Muscidae), and Lucilia illustris (Calliphoridae) belong to the subgroup $\mathrm{I}-\mathrm{c}$, and they were the important members not only in the forest but also in the residential area or the business quarters communities (Fig. 2).

The group II consists of four species. Among them, two phorid flies, Spiniphora atricostata and Woodiphora sp. 1, belong to the subgroup II-b, and one Sphaerocerid fly, Telomerina sp., belongs to the II-c.

The group III consists of seven species. Among them, two Phorid flies and Phaonia fuscata (Muscidae) belong to the III-a and Conicera sp. (Phoridae), Siphunculina simulata (Chloropidae) and Atherigona orizae (Muscidae) belong to the III-b. Flesh fly, Helicophagella melanura, is the only species belonging to the III-C.

The group IV consists of five species. Among them, only the species, Siphunculina aenea (Chloropidae) belongs to the subgroup IV-b. This species was collected abundantly in the urban forest and the residential area with plenty of garden trees or flower beds, but could not be collected in the business quarters, and a few individuals were collected in the residential area with few garden trees or flower beds. Four species, D. busckii (Drosophilidae), Tephrochlamys japonica (Heleomyzidae), Parasarcophaga similis and $P$. albiceps (Sarcophagidae), belong to the subgroup IV $-\mathrm{c}$, and they were the main members of the fly community in the urban area.

The group $\mathrm{V}$ consists of three species, Megaselia sp. 2 (Phoridae), Aldrichina grahami, and Calliphora vicina (Calliphoridae). They belong to the subgroup $\mathrm{V}-\mathrm{c}$.

The communities in the forest consist chiefly of the flies belonging to the group $\mathrm{I}$, and a few flies which seem to flow in from the neighbouring environments join the communities. However, in the urban forest, the community lacks the subgroup $\mathrm{I}-\mathrm{a}$, and the flies belonging to the group IV constitute the community in a high ratio instead of the subgroup I-a.
In the grassy areas, the flies belonging to the group III are dominant species. However the ratios are only $46 \%$ and $66 \%$ in site $H$ and $G$ respectively. The other flies belong mainly to the subgroup $\mathrm{I}-\mathrm{c}$, IV-c, I-b.

The communities in the residential areas and the business quarters consist fundamentally of the flies belonging to the subgroup $\mathrm{c}$, such as IV $-\mathrm{c}, \mathrm{V}-\mathrm{c}, \mathrm{I}-\mathrm{c}$. The ratio of the subgroup $\mathrm{V}-\mathrm{c}$ is high $(30.9 \%)$ in the business quarters. But in the residential area with plenty of garden trees or flower beds, its ratio is very low (2.3\%). The flies belonging to the subgroup b, especially the subgroup IV-b, constitute the community occupying rather high ratio, while they are very rarely in the areas with few garden trees or flower beds (Fig. 2).

Tephrochlamys japonica, Parasarcophaga albiceps, $P$. similis, and Megaselia sp. 1 were the main members of the communities in the residential areas, and Siphunculina aenea, Drosophila coracina, and Hydrotaea ignava were also the dominant species in the area with plenty of garden trees or flower beds.

Megaselia sp. 1, M. sp. 2, Drosophila busckii, Tephrochlamys japonica, Parasarcophaga albiceps, $P$. similis, Aldrichina grahami, and Calliphora vicina were the main members of the community in the business quarters.

In addition to the species listed above, there were some well known synanthropic species, Hemipyrellia ligurriens and Lucilia sericata (Hayashi and Shinonaga, 1979; Kurahashi, 1982). These were not collected in the suburban sites, and only few specimens obtained in the urban sites. Sarcorohdendorfia mimobasalis was not collected in the suburban sites, but collected abundantly in the urban forest, while $S$. antilope was the reverse. These two species seem to partition their habitats between the urban and suburban environments in the study areas. Three Anthomyia species, A. avisignata, A. plumiseta and $A$. illocata also seem to partition their 
habitats. A. avisignata was found in the grassy area, $A$. plumiseta in the forest, and $A$. illocata in the business quarters.

\section{Discussion}

The classification of the habitats based on the species compositions and its relative frequencies has been studied in the group of Drosophilid flies by Minami et al. (1979) or Toda (1984). They classified the habitats into following five categories: Forest, Water side, Hygrophilous herbage stand, grassland, and Human habitation. The habitats of the flies which attracted to putrid flesh were classified into two types, i.e. forest and grassland environments (Uemoto et al., 1962). In the present study, the habitats of the flies which attracted to putrid flesh were claasified into four categories. These are Forest, Grassy area, Residential area, and Business quarters.

Table 2 shows number of species, number of specimens collected, and average diversity using Shannon-Weaver function $\left(H^{\prime}\right)$ in each trapping site. The forest communities were characterized by having a large number of individuals and species, and also average diversity. Among the forest communities (D, E and $\mathrm{F})$, the community $\mathrm{D}$ was somewhat different from $E$ and $F$. The number of species and $H^{\prime}$ value was rather smaller than that of $\mathrm{E}$ or $\mathrm{F}$. And the community contained the flies belonging to the subgroup IV-c or IV-b in high ratio (Fig. 2). Site D is situated in urban area, and is surrounded by human dwellings. Therefore, it is suggested that the fly community of the urban forest is rather influenced by the inflow of the flies which inhabit in the surrounding human habitation, and the community structure has become more simple in comparison with the suburban forest.

Among the flies belonging to the subgroup I-b, Calliphora nigribarbis and Drosophila curviceps are known as flies which migrate seasonally (Kurahashi et al., 1991; Kimura and Beppu, 1993). Kurahashi and Suenaga (1995) suggested that Dryomyza formosa may also migrate seasonally. It is supposed that these three species may join the urban forest community by seasonal migration for spawning eggs.

The grassy area communities in this study tended to have a smaller number of species and average diversity in comparison with the forest community. Only seven dominant species were obtained from the grassy areas in comparison with 28 species from the forests. The results of the surveys show that the number of flies belong to the group III account for $46 \%$ in site $\mathrm{H}$ and $66 \%$ in site $\mathrm{G}$, nevertheless, species which belong to the group IV account for $15 \%$ in site $\mathrm{H}$ and $9 \%$ in site $\mathrm{G}$. Considering these results, it is suggested that these communities, especially in site $\mathrm{H}$, is influenced by the inflow of the flies which inhabit in the neighbouring human habitation.

The fly communities of the residential areas, especially in $\mathrm{B}$, were characterized by a small number of species and individuals. The average diversity of site $B$ was very small value. This probably reflected the lack of suitable breeding sources, such as carrion or animal feces. Comparing average diversity between sites $B$ and $C$,

Table 2. Number of species, number of specimens, and average diversity in 8 trapping sites.

\begin{tabular}{lrrrrrrrr}
\hline & \multicolumn{7}{c}{ Trapping site } \\
\cline { 2 - 9 } & A & B & C & D & E & F & G & H \\
\hline Number of species & 36 & 30 & 62 & 76 & 105 & 114 & 87 & 72 \\
\hline Number of specimens & 266 & 436 & 1376 & 3103 & 3207 & 5822 & 3473 & 1071 \\
\hline $\begin{array}{c}\text { Average diversity using Shannon-Weaver } \\
\text { function }\left(H^{\prime}, \text { unit: bit) }\right.\end{array}$ & 4.17 & 2.95 & 3.66 & 4.54 & 4.87 & 4.92 & 3.67 & 4.25 \\
\hline
\end{tabular}


the value in $\mathrm{C}(3.66)$ was larger than in $\mathrm{B}$ (2.95), and flies belonging to the subgroups I-b, and III-b were almost absent in site $\mathrm{B}$, while somew hat present in site $\mathrm{C}$. It is suggested that the diversity of fly community of residential area depends on amount of garden trees or flower beds.

The fly community in the business quarters was characerized by a very small number of individuals and rather large value of average diversity (4.17). A very small number of individuals suggests that there was little breeding sources in site A. And it is considered that the flies, which emerge there, become low density immediately by dispersion. Although the number of species was small (36 species), average diversity was large. This means that the eveness of the community was large. It seems that the fly community in the business quaters consists mainly of the flies which migrate from adjacent communities. Therefore, it is considered that the number of flies is always small and then the eveness of the community become large. And it is also considered that the fly community in site $\mathrm{A}$ is always changeable and influenced by climate, seasonal migration (as an example, seasonal migration of Aldrichina grahami, Kurahashi et al., 1991; Arakawa et al., 1991), or some other artificial environmental conditions, and so on.

\section{ACKNOWLEDGEMENTS}

I wish to express my sincere thanks to Dr. S. Shinonaga of Tokyo Medical and Dental University for his kind advice, identifing specimens and reading the manuscript. My thanks are also due to Drs. K. Beppu, Shinshu University; T. Goto, Forestry and Forest Products Reseach Institute; H. Hara, Hokkaido Forest Experiment Station; T. Hayashi, National Institute of Health; M. Iwasa, Obihiro University of Agriculture and Veterinary Medicine; the late K. Kaneko, Aichi Medical University; K. Kanmiya, Kurume University; H. Kurahashi, National Institute of Health; K. Nishida, Public Health Research Institute of Kobe City; T. Okada, Setagaya-ku, Tokyo; T. Okadome, Meijo University; M. Sasakawa, Hirakata City, Osaka; M. Suwa, Hokkaido University for the identifing specimens.

\section{REFERENCES}

Arakawa, R., K. Kamimura, M. Watanabe, H. Kurahashi and S. Kawai (1991) Migration of blow flies from low land to high land in Chubu Sangaku National Park, confirmed by mark-release and recapture method. Jpn. J. Sanit. Zool., 42: 275-280 (in Japanese with English summary).

Hayashi, A. and S. Shinonaga (1979) Hae-Seitai to Boujo-. 210 pp. Buneidou Co., Ltd., Tokyo. (in Japanese).

Kimura, M. T. and K. Beppu (1993) Climatic adaptations in the Drosophila immigrans species group: seasonal migration and thermal tolerance. Ecol. Entomol., 18: 141-149.

Kurahashi, H. (1982) Development of synanthropy of flies and urbanization. Konchu to Shizen, 17: 2-7 (in Japanese).

Kurahashi, H., S. Kawai and C. Shudo (1991) Seasonal migration of Japanese blow flies, Aldrichina grahami (Aldrich) and Calliphora nigribarbis Vollenhoven, observed by a mark and recapture methods on Hachijo Island, Tokyo. Jpn. J. Sanit. Zool., 42: 57-59 (in Japanese with English summary).

Kurahashi, H. and O. Suenaga (1995) Life history of Dryomyza formosa (Wiedemann) in Nagasaki Pref. Jpn. J. Sanit. Zool., 46, Suppl.: 59 (in Japanese).

Minami, N., M. J. Toda and K. Beppu (1979) Ecological structure of Drosophilid assemblage in Tomakomai Experiment Forest, Hokkaido University. Appendix: Some discussions on the calculations of niche parameters. Res. Bull. Coll. Exper. For., Coll. Agri., Hokkaido Univ., 36: 479-508 (in Japanese with English summary).

Mitsui, H. (1992) Fly community as a teaching material. J. BTAT, 28: 1-13 (in Japanese).

Mitsui, H. (1994) Flies (Diptera: Cyclorrhapha) emerged from six kind of breeding media in the urban and suburban areas in Tokyo. Jpn. J. Sanit. Zool., 45: 17-23 (in Japanese with English summary).

Pianka, E. R. (1973) The structure of lizard communities. Ann. Rev. Ecol. Syst., 44: 53-74.

Toda, M. J. (1984) Guild structure and its comparison between two local Drosophilid communities. Physiol. Ecol. Jpn., 21: 131-172.

Uemoto, K., K. Matsuo, S. Kitamura and K. Toita (1962) Ecological studies on flies in Kyoto. II. Habitat segregation of adult flies. Jpn. J. Sanit. Zool., 13: 163-164 (in Japanese). 


\author{
摘要 \\ 東京の市街地と近郊のハエ群集の生態学的研究 \\ 三井偉由 \\ 東京都立山崎高等学校 \\ （干195 東京都町田市山崎町 9-1453-1）
}

市街地で腐肉に誘引されるハエ群集の特徴を調べるた めに, 東京の市街地と近郊で, 1990-1992 年の 3 年間, 毎月 1 回べイト・トラップを使ってハエを採集し，その 結果を比較した. トラップは環境の異なる8 か所に設置 し, 3 年間で 24 科, 179 種, 18,754 個体の環縫要目の 八エが採集された.8 か所の八エ群集について, Pianka の $\alpha$ 指数を用いて計算した類似度をすとにして群分析 を行った結果, 八エの生息瓄境は森林, 草地, 住宅地, ビジネス街の 4 つの型に分けられた．また，おのおのの 調查地点で採集された八エの $85 \%$ を占める種を優占種 として，合計 47 種の優占種を選び，その優占種の 8 地 点での採集状況を比較した。 その結果, 47 種のハエは 4
つの型の生息環境に対応する 4 つのグループと森林と 草地で同じように採集された八エの合計 5 つのグルー

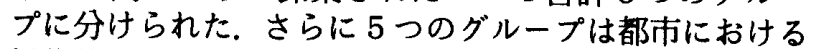
採集状況から，森林も含めて都市ではほとんど採集され なかったハエ, ビジネス街や緑の少ない住宅地ではほと んよ゙採集されなかったハエ, 住宅地やビジネス街で普通 に採集された八エの3つのサブグループに分けられた。 ビジネス街の八エ群集は個体数が極めて少なく，種数も 少ないが, 平均多様度が大きいのが特徴で, 優占種は, ミバェ科の 1 種 Megaselia sp. 1 とM. sp. 2, ヒョウモ ンショウジョウバエ, チャバネトゲハネバエ, ゲンロク ニクバエ, ナミニクバェ, ケブカクロバエ, ホホアカク ロバェであった. 住宅地の八エ群集は, 特に緑の少ない 地域では個体数, 種数ともに少なく, 平均多様度も小さ いのが特徴で, 優占種はノミバエ科の 1 種 Megaselia sp. 1, チャバネトゲハネバエ, ゲンロクニクバエ, ナミ ニクバェであった. 緑の多い住宅地では個体数, 種数之 あに增加し, 平均多様度あ大きくなった。 上記 4 種の優 占種の他にクロッヤショウジョウバエ, ヒメクロバェ, キモグリバエ科の 1 種 Siphunculina aenea も多かった。 